\title{
Marlowe's Strange Cities
}

\author{
ADAM HANSEN
}

UNIVERSITY OF NORTHUMBRIA

...it is part of morality not to be at home in one's home. ${ }^{1}$

\section{Introduction}

On March $1^{\text {st }}$ 1593, Parliament debated a Bill concerning the economic and social effects of foreign-born immigrants, displaced by the Continent's wars of religion, on English trades and communities. As the debate went back and forth, Henry Finch, newly-elected MP a month before for Canterbury (somewhere that had in recent years accommodated many such immigrants, and also the home city of Christopher Marlowe), affirmed: "Our nation is sure more blessed for their sakes. ... They are strangers now, we may be strangers hereafter. So let us do as we would be done to."2 Beyond noting the socio-economic benefits to England and its cities from accepting immigrant "strangers," in the face of others' concerns Finch's arguments advocated an ethics of inclusion, fairness, and sympathy. Prefiguring Adorno's dictum above, Finch's fellow-feeling for strangers petitioned his listeners in 1590s London to see themselves differently, in estranged ways, as potential strangers at some point, thereby imagining what it must be like "not to be at home in one's home." In his view, more connected than divided a strange 'them' and 'us'. Finch had history on his side as he tried to unsettle binary discriminations in this way. Others - including foreign strangers, whether positively or negatively perceived - were "an ever-present constituent of Englishness in this period," both materially and ideologically. ${ }^{3}$ As Scott Oldenburg notes: "Immigrants rented from Englishmen, and vice versa; immigrants worked in the households of the English, and

This article began life as a keynote at the Cities of Strangeness, 1350-1700 conference (Manchester University, 11 May 2018). I am grateful to the organisers Annie Dickinson and Laura Swift for their efforts and enthusiasm, as I am also to this article's anonymous reviewers.

\footnotetext{
${ }^{1}$ Theodor Adorno, Minima Moralia: Reflections from Damaged Life, trans. E. F. N. Jephcott (1974; repr., London: Verso, 2000), 39.

${ }^{2}$ Cited in Sir Simonds D'Ewes, The Journals of All the Parliaments During the Reign of Queen Elizabeth (Shannon, Ireland, 1682), 511; British History Online, accessed January 2019, http://www.britishhistory.ac.uk/no-series/jrnl-parliament-eliz1. For drawing my attention to Finch, I am grateful to the work of the TIDE project, looking at "Travel, Transculturality, and Identity in England c.1550-1700." Accessed January 2019, http://www.tideproject.uk/.

${ }^{3}$ Claire McEachern, The Poetics of English Nationhood, 1590-1612 (Cambridge: Cambridge University Press, 1996), 25 .
} 
vice versa; and immigrants and English married one another." ${ }^{\prime 4}$ In light of these material and ideological conditions, this article explores how Marlowe's plays and poems share, envisage, and enable the views of someone like Finch. How does Marlowe provoke his audiences to question divisions, and perceive connections, between the identities of strangers and the urban communities they came to inhabit? Answering this question requires rethinking the strangeness and unfamiliarity of Marlowe's city-scapes in relation to the perplexing experiences of strangers and strangeness in early modern London, experiences which were "essential to an English understanding" of the city at the time. ${ }^{5}$ Marlowe therefore both depicts strange cities and connects them to cities, like London, in which strangers had a presence. Through understanding this we will see how and why Marlowe makes strange cities familiar to his audiences, and how he identifies the uncanny inherence of the stranger to familiar places, like London. Doing so involves historicising the connections between cities and nations, strangers and strangeness, that we see framing identities in Marlowe's texts and contexts; it also involves theorising these connections and identities, in part in light of Freudian ideas of the uncanny, but also in relation to discourses of immigration in our time.

When thinking of strangeness, the city and the nation, it is important to remember that in the early modern period, England's capital was no simple synecdoche for the country"London was not all England"- though it was sometimes perceived as such by people at the time, notably foreign visitors: "he who sightsees London...is properly acquainted with England." "So how Marlowe and others staged strangers and cities had implications for understanding national identity. Lloyd Kermode suggests staging aliens and strangers had two functions, which fall roughly into two periods. Early Elizabethan drama tended to "demonize" otherness to "define Englishness"; later Elizabethan drama was more concerned with dramatizing ways of absorbing the alien. This was, he suggests, seen as "not just acceptable, but also necessary," as it led to a "reformed, expanded, revitalized" Englishness. Another effect of this was, however, the way such staging generated an "always politically equivocal definition of the English self." "7 Marlowe, at once familiar and experimental with earlier dramatic modes, does all these things. In so doing, he anticipates the way later genres

\footnotetext{
${ }^{4}$ Scott Oldenburg, Alien Albion: Literature and Immigration in Early Modern England (Toronto: University of Toronto Press, 2015), 13.

${ }^{5}$ Lloyd Edward Kermode, Aliens and Englishness in Elizabethan Drama (Cambridge: Cambridge University Press, 2009), 10.

${ }^{6}$ Susan Brigden, New Worlds, Lost Worlds: The Rule of the Tudors, 1485-1603 (Harmondsworth: Penguin, 2000), 214; Thomas Platter (1599), in The Journals of Two Travellers in Elizabethan and Early Stuart England: Thomas Platter and Horatio Busino (London: Caliban Books, 1995), 10.

${ }^{7}$ Kermode, Aliens and Englishness, 4-5.
} 
which were "focused on the topography of London" (such as city comedy) would make great play of the "unstable distinction between aliens and native Londoners," whether they were "aggressively...promoting Englishness," or "rendering the unfamiliar intelligible." led some critics to convincingly argue that while some of Marlowe's contemporaries "sought to foment distrust and resentment of strangers," in plays like The Massacre at Paris, Marlowe creates "sympathy for and understanding of them." This article develops this perspective.

Arguably, though, Marlowe is hardly an obvious candidate for thinking about the early modern city's immigrant strangers, especially when compared to Ben Jonson or Thomas Middleton. He was not born and did not study in London, and he did not set any of his plays there (apart from some bits of Edward II). Moreover, it could be a mistake to identify Marlowe as someone querying discrimination against immigrants, when he was implicated in stirring up concerns about them. In early May 1593, two months after Finch's speech, and the same month Marlowe was murdered, this was attached to the door of Austin Friars church in London's Broad Street, a church which had been "granted...to the Dutch nation" since 1550 :

Ye strangers yt doe inhabite in this lande Note this same writing doe it vnderstand Conceit it well for savegard of your lyves Your goods, your children, \& your dearest wives Your Machiavellian Marchant spoyles the state, ... And like the Jewes, you eate us vp as bread... strangers make our harts to ake For which our swords are whet, to shedd their blood And for a truth let it be vnderstoode Fly, Flye, \& never returne. per. Tamberlaine ${ }^{10}$

As Lloyd Kermode avers, Robert Wilson's The Three Ladies of London, republished in 1592 after appearing first on stage in the 1580s, was "a play more directly concerned with the complaints in the [Dutch] libel than anything Marlowe produced." ${ }^{11}$ Nonetheless, to Eric Griffin, the libel appropriates Marlowe's "rhetorical force and his popularity" in ways that evince "discursive parallels" with his work, suggesting the libel's writers were "acquainted

\footnotetext{
${ }^{8}$ Jean E. Howard, Theater of a City: The Places of London Comedy, 1598-1642 (Philadelphia: University of Pennsylvania Press, 2007), 29, 39-41.

${ }^{9}$ Oldenburg, Alien Albion, 69.

${ }^{10}$ Adrian Prockter and Robert Taylor, The A to Z of Elizabethan London (Kent: Harry Margary, 1979), 34. The "Dutch Libel" is reproduced in Arthur Freeman, "Marlowe, Kyd, and the Dutch Church Libel," English Literary Renaissance 3, no. 1 (Winter 1973): 44-52.

${ }^{11}$ Kermode, Aliens and Englishness, 72.
} 
enough" with those works to perceive how Marlowe himself had "tapped into a source of collective anxiety" about strangers, just as they sought to. ${ }^{12}$ Attributing the Libel to "Tamberlaine" exemplifies this. Both parts of Tamburlaine are full of strange cities getting wiped off the map, and Tamburlaine's boasts are as repetitive as the alliteration that underpins them: in Part 1, he foresees "conquered kingdoms...cities sack'd" (Tamburlaine, 1.1.2.192) and in Part 2 he promises "I will.../Conquer, sack and utterly consume / Your cities" (2.4.2.192-94). Since all these cities are far away from the London stage, geographically and theologically, the plays perhaps fulfil every English xenophobe's fantasy. As the conceit of the Dutch libel suggests, and as Emily Bartels taught us, perhaps Marlowe $i$ the perfect person to look to for "“"spectacle[s] of strangeness":" "To enter upon the Marlovian stage is to enter a landscape filled with strangers." ${ }^{13}$ Bartels brilliantly detailed how Marlowe obsessively presents strange figures who would have been "alienated from or marginalized within English society" and were situated "within a foreign setting." 14 She attributes this obsession to Marlowe's response to "an increasingly dominant cultural obsession with foreign worlds and peoples, emerging with England's nascent imperialism," an obsession, Bartels says, that was powerfully manifested in the commercial theatre of early modern London. ${ }^{15}$ But, for all Bartels' considerable insights, that crucial last termLondon-does not feature much in her discussions, nor does all it implies about the urban world in the period as a place where such obsessions with strangers and strangeness might localize, focus, and find expression. ${ }^{16}$ In other words, there is much to learn when we think about cities as places where the commingling of the global and the local was acutely evident, and thus as places that accommodated stages that animated, estranged and unsettled audiences, even as they drew on familiar tropes and genres.

So the argument that follows is going to try to do something Bartels did not, that is, connect Marlowe's spectacles of strangeness with the environment of the city. Writing in and of early modern London often functioned as a way to deal with strangeness, and so to make

\footnotetext{
${ }^{12}$ Eric Griffin, "Shakespeare, Marlowe and the Stranger Crisis of the Early 1590s," in Shakespeare and Immigration, ed. Ruben Espinosa and David Ruiter (Farnham: Ashgate, 2016), 23-24.

${ }^{13}$ Emily C. Bartels, Spectacles of Strangeness: Imperialism, Alienation and Marlowe (Philadelphia: University of Pennsylvania Press, 1993), 3-4. Bartels notes the critical heritage underpinning her focus on strangeness $(177$, n.2): "I borrow the phrase [spectacles of strangeness] from [Steven] Mullaney [in The Place of the Stage: License, Play, and Power in Renaissance England (Chicago: University of Chicago Press, 1988)], who borrows it from Ben Jonson's description of the antimasque in the Masque of Queens (Place of the Stage, 64)."

${ }^{14}$ Bartels, 3.

${ }^{15}$ Bartels, 3.

${ }^{16}$ We might note that in the recent and excellent collection co-edited by Bartels with Emma Smith, Christopher Marlowe in Context (Cambridge: Cambridge University Press, 2015), "London," "urban" and "city" do not feature in the index, nor in the titles or focus of any chapters.
} 
familiar and comprehensible locations that may well have been unfamiliar to incomers, and to 'natives' in a changing city. ${ }^{17}$ Understanding drama about aliens was "essential to an English understanding of London" in the Elizabethan period. ${ }^{18}$ In this sense, literature worked to make the strange less strange. But, as we will see with Marlowe, some writers also sought to make strange what people thought they already knew. Again and again, in Marlowe's works we see figures and places becoming uncannily unfamiliar — strange - to themselves.

\section{The City and the Stranger, Past and Present}

To develop Bartels's ideas in this way requires both clarifying the period's sense of what strangers were, and understanding how England's early modern cities became associated with them. Laura Hunt Yungblut determines a strict definition as follows: "The designations 'alien' and 'stranger' were used in the early modern period to refer to foreign-born individuals residing in the realm but with none of the franchises of native Englishmen." 19 Yet as Kermode notes, "usage is not perfectly consistent" in the period. ${ }^{20}$ Accordingly, scholars have deployed “the terms 'alien,' 'stranger' and immigrant' interchangeably." ${ }^{21}$ Marlowe himself never uses the word 'alien'. Assuming he did not write the Dutch Libel, he did, however, use the word "strange" and its variant spellings and cognates some 40 times, and the word city (and its variants and cognates) over 60 times. ${ }^{22}$ Crucially, his use of "stranger" intensifies and becomes significantly frequent when spoken in urban settings-Rome, Carthage, Valletta. In these cities, exotic to his audiences, characters use "stranger" to describe someone from a foreign country (as Aeneas is to Dido), but also to describe someone who is seen as a stranger in a country where they reside (even if they do not consider it home-like Barabas).

The frequent and significant connections Marlowe makes between cities and strangers were rooted in the long histories and contemporary realities of urban life in early modern

\footnotetext{
${ }^{17}$ See Ian Archer, "The Nostalgia of John Stow," in The Theatrical City: Culture, Theatre and Politics in London 1576-1649, ed. David L. Smith, Richard Strier and David Bevington (Cambridge: Cambridge University Press, 1995), 17-34; and Craig Dionne, "Fashioning Outlaws: The Early Modern Rogue and Urban Culture," in Rogues and Early Modern English Culture, ed. Craig Dionne and Steve Mentz (Ann Arbor: University of Michigan Press, 2004), 33-62.

${ }^{18}$ Kermode, Aliens and Englishness, 10.

${ }^{19}$ Laura Hunt Yungblut, Strangers Settled Here Amongst Us: Policies, perceptions and the presence of aliens in Elizabethan England (London: Routledge, 1996), 128n1.

${ }^{20}$ Kermode, Aliens and Englishness, 2.

${ }^{21}$ Yungblut, Strangers Settled Here Amongst Us, 128n1. On this interchangeability, see also Oldenburg, Alien Albion, 3-4; and the usefully historicised keywords provided in the TIDE project.

${ }^{22}$ See Robert J. Fehrenbach, Lea Ann Boone, and Mario A. Di Cesare, eds., A Concordance to the Plays, Poems, and Translations of Christopher Marlowe (Ithaca, NY: Cornell University Press, 1984).
} 
England: "Foreigners had become a familiar part of the English urban landscape as early as the late twelfth and early thirteenth centuries." ${ }^{23}$ Marlowe grew up in a family that had itself moved to just within the walls of a cathedral city fundamental to the period's conflicted and estranged religious and political identities, but which was also affected by the impact of the Reformation on the continent and its strangers: "at this time Canterbury was filled with émigrés, known as 'Flemings' or 'Dutch', who received news reports from across the Channel that would have stirred [Marlowe's] mind." ${ }^{24}$ Since Canterbury had taken in these refugees to ease the pressure on places like Sandwich on the coast, it became "one of several towns which all had a sizeable alien colony." ${ }^{25}$ Marlowe's own father was apprenticed to "Gerard Richardson, an immigrant shoemaker living in Northgate Ward in Canterbury." ${ }^{26}$ In his biography of Marlowe, David Riggs eloquently articulates the potential implications of these realities on his subject's thinking:

The conflicts that plagued Canterbury from the 1530 s to the $1570 \mathrm{~s}$ [meant]...Christopher Marlowe, the son of immigrants situated on the margins of their community, spent most of his life in a place where elementary structures of religious belief were constantly being discredited. ${ }^{27}$

Oldenburg notes that while several historians have observed "a relatively peaceful coexistence" in "English-immigrant relations in Canterbury," the city's authorities were "as early as 1582 alarmed by the growth of the immigrant community" there. ${ }^{28}$ Similarly, if the capital manifested a concentration of strangers making welcome contributions to the economy, then it also became a focus for anxieties about them: "foreign communities in London" were seen as "a potentially unpredictable element." ${ }^{29}$ During the reign of Elizabeth I, "the metropolis had the largest number of resident aliens." ${ }^{30}$ For mutual aid, for trade, or for worship, these strangers congregated in particular places in London: "wards with the highest concentrations of aliens comprised the easternmost end of the City itself, and similarly high numbers are found in the eastern suburbs." ${ }^{31}$ On moving to and working in

\footnotetext{
${ }^{23}$ Yungblut, Strangers Settled Here Amongst Us, 10.

${ }^{24}$ Park Honan, Christopher Marlowe: Poet and Spy (Oxford: Oxford University Press, 2005), 32.

${ }^{25}$ Yungblut, Strangers Settled Here Amongst Us, 32; see 58-59 and 89.

${ }^{26}$ Oldenburg, 62.

${ }^{27}$ David Riggs, The World of Christopher Marlowe (London: Faber and Faber, 2004), 13-14.

${ }^{28}$ Oldenburg, Alien Albion, 63; citing Anne M. Oakley, "The Canterbury Walloon Congregation from Elizabeth I to Laud," in Huguenots in Britain and Their French Background, 1550-1800, ed. Irene Scouloudi (Totowa, NJ: Barnes and Noble, 1987), 56-71.

${ }^{29}$ Andrew Pettegree, Foreign Protestant Communities in Sixteenth-Century London (Oxford: Clarendon Press, 1986), 4.

${ }^{30}$ Yungblut, Strangers Settled Here Amongst Us, 13

31 Yungblut, 27.
} 
Shoreditch at some point in the 1580s, Marlowe would then have found himself in amongst these suburban, extramural areas, and their strange inhabitants. He was a stranger on the edge of a city of strangers, a city much larger than but still comparable to ones he had known:

London was soaking up vast numbers of English men and women, as well as Scots, Irish, and others from abroad ... By the late sixteenth century, 4\% to 5\% of London's population were aliens, including Scots Irish, Welsh, French, Dutch, and a handful of Jews and Africans. Scots, Irish and welsh came to London for the same reasons as English migrants. So did continental cloth workers. Dutch, Flemish, and French Protestants... were also feeling religious persecution. ${ }^{32}$

As it is now, London was a hybrid city of citizens, aliens, and visitors. Immigration rose, and so too, at times, did conflicts, with some Londoners reacting violently to new arrivals. Yet Yungblut explains that reactions to immigrants displayed a "dichotomy of attitudes" that were "neither simple nor clear." 33 Outright unrest was not common, and new arrivals contributed skills and labour to a range of industries and trades, helping London outpace the intolerant or conflicted cities they had left (like Antwerp).

The effects of strangers on a city like London were cultural as well as economic. The historian Laura Wright notes that "English as a second language was spoken in the capital," and that "continental languages and continental accents were heard daily"; she continues: "Early modern Londoners heard foreign language systems spoken in their city, both from within and outside Britain, and forms of English that were informed by other substrate languages." 34 This had an impact on literary production in the city. Discussing linguistic and cultural hybridity in the period, Steven Mullaney famously observed:

English itself began to study strange tongues. ... The vernacular was not a fixed linguistic system so much as a linguistic crossroads, a field where many languagesforeign tongues, local dialects, Latin and Greek-intersected; ... The voice of the Other, of the barbarous, sounded in the throat whenever the mother tongue was spoken; one's own tongue was strange yet familiar. ${ }^{35}$

Certain places, like cities, offered real as well as figurative crossroads where this could happen. And when conditions impressed upon creative minds the plasticity and connectedness, as well as the exclusivity and distinctness, of the rhythms, idioms, roots and

\footnotetext{
${ }^{32}$ Robert O. Bucholz and Joseph P. Ward, London: A Social and Cultural History, 1550-1750 (Cambridge: Cambridge University Press, 2012), 68-69.

${ }^{33}$ Yungblut, Strangers Settled Here Amongst Us, 44.

${ }^{34}$ Laura Wright, "Speaking and listening in early modern London," in The City and the Senses: Urban Culture Since 1500, ed. Alex Cowan and Jill Steward (Aldershot: Ashgate, 2007), 63, 73.

${ }^{35}$ Steven Mullaney, The Place of the Stage: License, Play, and Power in Renaissance England (Chicago: University of Chicago Press, 1995), 77-79.
} 
possibilities of particular idiolects and languages, innovative ways of thinking and speaking about the self and others became available. In other words, people like Marlowe were engaging through their education and their situation in cities with foreign stories and texts and languages. As they did this, they started to see and hear their own language in different ways, as a stranger might. This, in turn, allowed people like Marlowe to do new and uncanny things with their language, including write "that strange stuff called literature," in ways that were effective and engaging precisely because of how they made language strange. ${ }^{36}$ Every strange linguistic "functional shift" that Philip Davies identifies as "central...to Shakespearean thinking" is potent because of how this plasticity defamiliarises, or estranges, the structures of English: this could be a repetition that provokes a re-evaluation of the word repeated, or the "ever-fixed name" of a noun becoming a "fast-released verb," or the "structural difference" and conditionality promised by "apparently simple little words such as 'else' or 'but'" (or "If'). ${ }^{37}$ But, as others have noted, exactly these defamiliarising, transformative processes — what George Puttenham in 1589 called "enallage or the figure of exchange"- are potent and present in Marlowe too: "The parts of speech, like the spheres that form his cosmos, are ever-moving." 38

People at the time recognised the way a city like London could enable these shifts and exchanges, of ideas, words, and identities. Thomas Heywood's An Apology for Actors (1612) attributes the success of London's playhouses to the same forces that made Rome's so successful: each city is a "metropolis, a place whither all the nations knowne under the sunne resorted...to affoord them all choyce of pastimes, sports, and recreations. ${ }^{, 39}$ As the scholar and writer Eva Hoffman has put it more recently, in her profound autobiographical account of being an émigré Jewish Pole, learning English in post-War North America: "Each language makes the other relative. Like everybody, I am the sum of my languages...though perhaps I tend to be more aware than most of the fractures between them, and of the building blocks." 40 With such "fractures," and the consequent restructuring of the parts of speech they make possible, linguistic and social hybridity finds literary forms.

This reference to Hoffman is not meant to offer an ahistorical aside, but to alert us that these hybridized encounters between 'stranger' and 'native' in life and art have been

\footnotetext{
${ }^{36}$ Nicholas Royle, The Uncanny (Manchester: Manchester University Press, 2003), 5.

${ }^{37}$ Philip Davies, Shakespeare Thinking (London: Continuum, 2007), 73, 21, 29, 40.

${ }^{38}$ George Puttenham, The Arte of English Poesie, cited in Davies, 76; Harry Levin, The Overreacher: A Study of Christopher Marlowe (London: Faber and Faber, 1954), 31.

${ }^{39}$ Qtd. in E. K. Chambers, The Elizabethan Stage (Oxford: Clarendon Press, 1923), 4: 251-52.

${ }^{40}$ Eva Hoffman, Lost in Translation: A Life in a New Language (London: Vintage, 1998), 273.
} 
persistent and are ongoing: "Migration issues are not restricted to the modern era." 41 The way we see how strangeness and "strangers" were constructed in the past is conditioned by how people see and experience these things today. When the current UK Border Force patrols the Mediterranean and the Channel, it is hard not to draw parallels with the activities of William Bourne, captain of the Phoenix, "hired" in 1572 to police Thames traffic, and especially "all strangers. $" 42$

Of course, the scale and intensity of migration and responses to it now are clearly different. Equally, the conditions in which some people see and experience migration are diverse, complex, and at once humbling and dehumanising. Yet what we could theorise as an epistemology or phenomenology of strangeness might now include, amongst other aspects, ideas about Freud's concept of the uncanny. As Freud first begins to explore what he means by uncanny, he suggests 'The German word 'unheimlich' is obviously the opposite of 'heimlich' ['homely'], 'heimisch' ['native'] — the opposite of what is familiar, and we are tempted to conclude that what is 'uncanny' is frightening precisely because it is not known and familiar." ${ }^{43}$ Elsewhere, he glosses " Heimlich" as "belonging to the house, not strange, familiar, tame, intimate, friendly, etc." "44 This might suggest the stranger is automatically uncanny, because inherently unhomely. Not so, says Freud: "Naturally not everything that is new and unfamiliar is frightening, however; the relation is not capable of inversion.... Something has to be added to what is novel and unfamiliar in order to make it uncanny." $" 45$ Part of what makes an uncanny thing uncanny is that is appears within, and with the characteristics of, the familiar; it is not just "novel and unfamiliar." One commentator on Freud's ideas puts it like this:

$[\mathrm{T}]$ he uncanny is not simply an experience of strangeness or alienation. More specifically, it is a peculiar commingling of the familiar and unfamiliar. It can take the form of something familiar unexpectedly arising in a strange and unfamiliar context, or of something strange and unfamiliar unexpectedly arising in a familiar context. It can consist in a sense of homeliness uprooted, the revelation of something unhomely at the heart of hearth and home. It might arise from the seemingly mechanical repetition of a word, such as 'it'.

\footnotetext{
${ }^{41}$ Yungblut, Strangers Settled Here Amongst Us, 117.

42 Yungblut, 87.

${ }^{43}$ Freud, "The Uncanny," in The Penguin Freud Library XIV: Art and Literature, ed. Albert Dickson

(Harmondsworth: Penguin, 1990), 341.

${ }^{44}$ Freud, 342.

${ }^{45}$ Freud, 341.

${ }^{46}$ Royle, The Uncanny, 1.
} 
As we will see, Marlowe's strange cities, often cities where strangers are a feature, are strange precisely because they repeatedly stage this uncanny "commingling," through realising the interorientation of the familiar and unfamiliar. In this regard, Freud's ideas can help us understand what Marlowe is doing as he stages Rome or Carthage. Freud's ideas might also help us understand what we are doing to contemporary migrants to former imperial heartlands, too. They may be 'strangers' but their strangeness discloses uncomfortable truths. Their presence becomes uncanny as they embody the strangeness that is always already within supposedly familiar forms of national identity. They inhere because of the infrastructures of empire, because of the long histories of hybridity and multiculturalism that so many nations now disavow or repress, and because of such nations' current or recent involvement in what is impelling migration globally: climate change, wars, political instability, and economic inequality. This does not mean that knowing Freud - or Marlowe-will help generate sympathy for contemporary migrants, or improve their lives; it might, though, explain why sympathy is so often lacking, and why some people subject other people to such repressive conditions. What literature, history, or theory tell us is one thing; harsh reality is another. Of course, it would seem that for many contemporary communities, identifying who is a stranger, and then policing, distancing or excising them, is vital business. But it is ultimately deathly and self-destructive business, as the late, lamented Zygmunt Bauman alerts us:

the sole way out of the present discomforts and future woes leads through rejecting the treacherous temptations of separation; instead of refusing to face up to the realities of the 'one planet, one humanity' challenges of our times, washing our hands and fencing ourselves off from the annoying differences, dissimilarities and self-imposed estrangements, we must seek occasions to come into a close and increasingly intimate contact with them. ${ }^{47}$

The city can offer one place to realise this "intimate contact," where we can concentrate efforts to critique and incapacitate discrimination against others, including rather than excluding, however much those with power seek to create a "hostile environment" for them: "The city brings together people who are different, it intensifies the complexity of social life, it presents people to each other as strangers. All these aspects of urban experiencedifference, complexity, strangeness — afford resistance to domination." 48 To recollect

\footnotetext{
${ }^{47}$ Zygmunt Bauman, Strangers at Our Door (Cambridge: Polity, 2016), 18-19.

${ }^{48}$ Alan Travis, "Immigration bill: Theresa May defends plans to create 'hostile environment'," The Guardian (10 October 2013), accessed 18 October, 2018, https://www.theguardian.com/politics/2013/oct/10/immigrationbill-theresa-may-hostile-environment; Richard Sennett, Flesh and Stone: The Body and the City in Western Civilization (London: Faber and Faber, 1996), 25-26.
} 
Adorno's epigraph above, and the words of Henry Finch: being and doing good in one's home means understanding what it is to be displaced from one's home, and taking a critical view of what one's home does to those displaced.

As we can read the crises and opportunities of the early modern city in relation to ourselves, so people in the early modern period read other, strange cities in relation to themselves, especially on stage. This was in part due to what Darryll Grantley terms "anatopism," whereby "remote locations - in terms of geography, period or myth —were readily understood to represent English society in general, and even specifically London." 49 The reverse was also evident. Marlowe only uses the word "London" twice, but even when he does, as in Edward II, the city is described as being "as" somewhere else: "GAVESTON. The sight of London to my exil'd eyes / Is as Elysium to a new-come soul" (Edward II, 1.1.10-11). ${ }^{50}$ Marlowe's only other direct reference to London is no less significant for the displacement it enacts: "BARABAS. Florence, Venice, Antwerp, London, Seville, / Frankfort, Lubeck, Moscow and where not" (The Jew of Malta, 4.1.71-72). Here, London features as a part of a list with other notable global trading cities, suggesting its significance, but also its equivalence, connection, and interchangeability with them. At the theatre, the city could be at once a specific, felt somewhere, or anywhere, or nowhere.

\section{Cities of Strangers: The Jew of Malta}

As that quotation from Barabas suggests, The Jew of Malta is a good place to start when exploring the ways Marlowe connects strangeness and cities, because being strange in and to a city is at the heart of the play. This is evident in the discriminatory policies the Maltese set up to fund their defence against the Turkish invasion: "BARABAS. Are strangers with your tribute to be tax'd? / 2 KNIGHT. Have strangers leave with us to get their wealth? (1.2.5960). At moments like this, the play stages strangeness as incommensurable, damning otherness. As those lines suggest, there appears to be a binary of an 'us' penalizing an implicit 'them', with the 'us' having been waiting for the opportunity to do so: 'the Turkish demand allows rather than provokes what seems a previously calculated policy against the Jews." 51 That discriminatory, Christian 'us', penalizing a community marked as ethnically other, might also be seen to have included members of Marlowe's London audience:

\footnotetext{
${ }^{49}$ Darryll Grantley, London in Early Modern English Drama: Representing the Built Environment (Basingstoke: Palgrave Macmillan, 2008), 5.

${ }^{50}$ Unless otherwise stated, all references are to Christopher Marlowe, Complete Plays and Poems, ed. E. D. Pendry (London: Everyman, 1995).

${ }^{51}$ Bartels, Spectacles, 94.
} 
London's anti-Semitism thrived, and Marlowe, in embodying and satirically exaggerating it in a drama, risked contributing to it. By no means everyone who laughed, roared over, and applauded his Jewish villain would have found a satirical intent in his work. ${ }^{52}$

If this is the case, these discriminations are comparable to a moment in Ovid's Elegies, when Marlowe's priapic narrator tries to persuade a servant guarding the door of his mistress's house that she (and he) should not be treated like this, and draws on the idea that different sorts of people require different treatment and levels of control in a city and an empire like Rome: “A free-born wench no right 'tis up to lock, / So use we women of strange nations' stock" (3.4.33-34). Such lines advocate spatially demarcating the "strange" from the "freeborn" in Ovid's Rome, and maybe in Marlowe's London too, where surveys or "Returns" of strangers seemed to mark out areas where they were known to be concentrated. And yet Marlowe's writings, including the translations, complicate such clear-cut socio-spatial separations. Even as a series of poems like Ovid's Elegies might seem to demarcate 'strangers' from the rest, there are times when the adulterous narrator-lover takes on an identity as an outsider, to a married couple if not the city they all share. We can see this when the narrator advises their mistress to sin in secret: "The strumpet with the stranger will not do / Before the room be clear, and door put to" (3.13.9-10). There is another kind of demarcation here, but this time for an illicit liaison that makes the narrator, as elsewhere in the Elegies, a stranger to himself as desire estranges and disorients: "I cannot rule myself" (2.4.7). Moreover, the fact that the "stranger" lover is in the "room," or wants to be, shows that spatial separation is itself a reaction to the impossibility of keeping spaces secure and separate. In contrast, Marlowe's translations repeatedly set up a poetics of proximity, where desire lays siege to what keeps things apart, and where the interdependencies of the urban environment make this all the more possible: a "soldier," we're told, "breaks town gates," but a lover "his mistress' door" (1.9.15-20).

In turn, a play like The Jew of Malta could be argued to have been implicated in both the anti-Semitism that impelled the persecution of someone like Roderigo Lopez in the mid1590s, as well as a more general intolerance towards outsiders, as encapsulated by the Dutch Libel discussed above. However, as in the Elegies, Marlowe's work here and elsewhere does something different, to query the very ideological and material construction of demarcating binaries: "Marlowe's representations of the alien are about the representation of the alien, and the arbitrary, uncertain, and strategic ways in which difference is constructed." ${ }^{\circ 3}$ This is

\footnotetext{
${ }^{52}$ Honan, Christopher Marlowe, 254.

${ }^{53}$ Bartels, Spectacles, 14.
} 
particularly true in this play. Strangeness and the city concatenate again, in scenes that seem to emphasise Barabas' estrangement from the Maltese city-state in which he finds himself. We can see this in an exchange involving Barabas disguised as a wandering entertainer:

BELLAMIRA. Musician, hast been in Malta long?

BARABAS. Two, three, four month, madam.

ITHAMORE. Dost not know a Jew, one Barabas?

BARABAS. Very mush, monsieur, you no be his man?

PILIA-BORZA. His man?

ITHAMORE. I scorn the peasant: tell him so.

BARABAS [aside]. He knows it already.

ITHAMORE. 'Tis a strange thing of that Jew: he lives upon pickled grasshoppers and sauc'd mushrumps. ... He never put on clean shirt since he was circumcis'd.

(The Jew of Malta, 4.4.58-69)

There is complex irony at work here regarding being strange and estranged in a city. Barabas is pretending to be a stranger in the city, and thus estranged from his true identity as a Jewish merchant. But even that 'true identity' casts him as a stranger, and comprises features extrinsic to him, both by him and others, and he is at some critical remove from it. As Andrew Duxfield smartly recognises: "his histrionic performance of...stereotypes serves to highlight their fictive status, and positions him externally to them." ${ }^{54}$ In this instance, that identity is made strange to him by others, by being constructed as an other, with strange and disgusting habits. In other words, he is made strange to Malta as he is othered to himself. The irony complicates further because it is another other, Ithamore, doing the othering to make himself more at home when he is anything but. As Leslie Fiedler suggests, "the process which underlies the creation of stranger myths is, psychologically speaking, projection." ${ }^{55}$ In other words, when someone is made strange, this is often the result of someone else displacing their own strangeness. In Malta, insiders and outsiders both do this, and we can see it happening again in a later scene:

KATHERINE. Where is the Jew? Where is that murderer?

FERNEZE. In prison, till the law has pass'd on him.

Enter Officer.

OFFICER. My lord, the courtesan and her man are dead;

So is the Turk and Barabas the Jew.

FERNEZE. Dead?

OFFICER. Dead, my lord, and here they bring his body.

Bosco. This sudden death of his is very strange.

[Enter Officers, carrying Barabas as dead.]

FERNEZE. Wonder not at it, sir; the heavens are just.

Their deaths were like their lives; then think not of 'em.

\footnotetext{
${ }^{54}$ Andrew Duxfield, Christopher Marlowe and the Failure to Unify (Farnham: Ashgate, 2015), 94.

${ }^{55}$ Leslie A. Fiedler, The Stranger in Shakespeare (St. Albans: Paladin, 1974), 38.
} 
Since they are dead, let them be buried.

For the Jew's body, throw that o'er the walls,

To be a prey for vultures and wild beasts.

So, now away and fortify the town. (The Jew of Malta, 5.1.48-59)

The odd circumstances of Barabas' death apparently terminally estrange him; his posthumous exile confirms his strangeness to Malta, and pushes Ferneze to head off to "fortify" Malta's identity. Throwing Barabas over the walls separates him even from the other reprobates with whom he has been previously associated. To sections of Marlowe's London audience, this kind of extramural expulsion might have seemed like a disloyal stranger's just deserts; it might also have reflected the reality of many strangers being located in suburbs beyond London's walls. However we read this moment, it seemingly reinforces a binary separation between an 'us' within and an other without.

But Barabas is not dead; he has just drunk a "sleepy drink" of "poppy and cold mandrake juice" $(5.1 .60,80)$, from which he soon revives. And, in turn, chucking him out to "fortify" the city proves counterproductive: he immediately makes an alliance with the Turkish Calymath to defeat Maltese enemies like Ferneze and "be reveng'd on this accursed town" (5.1.61). However, reasoning he does not want to rule a city that "hates" him (5.2.29), and having done a deal with Ferneze for "Great sums of money" (5.2.85), Barabas doublecrosses the Turks to "set Malta free" (5.2.92). With Barabas having previously stated he is not bothered if the Turks "take the town" (1.1.188), the duplicity of this Machiavellian merchant might not be motivated by any desire to be at home in Malta, or loyalty to it, whoever rules. Yet Barabas does come to some kind of negative accommodation with Turks and Christians, stating "loving neither, will I live with both" (5.2.108). This accommodation, though, is not what makes him less of stranger. Instead, it is his willingness to be Machiavellian and duplicitous in a city-state "filled with hard-core policy-making Machiavells" that confirms he is no stranger to Malta's ways: "This is the life we Jews are us'd to lead; / And reason too, for Christians do the like" (5.2.112-13). ${ }^{56}$ Barabas's use of "us'd" suggests he is experienced at having to employ the kind of acts of "policy" (and indeed usury) he does, precisely because he is treated — or used — so badly by others he acts like. As Stephen Greenblatt succinctly put it: “Barabas’s avarice, egotism, duplicity, and murderous cunning do not signal his exclusion from the world of Malta, but his central place within it. ... Barabas is brought into being by the Christian society around him. ${ }^{" 57}$ Because

\footnotetext{
${ }^{56}$ Bartels, Spectacles, 92.

${ }^{57}$ Stephen Greenblatt, Renaissance Self-Fashioning: From More to Shakespeare (Chicago: University of Chicago Press, 1980), 206.
} 
Barabas embodies Malta's most mercenary values, he represents an uncomfortable, discomfiting presence, a reminder provoking disgust and repulsion: "The other may be feared because structured within an economy of the same." ${ }^{58}$ What we are seeing is that in this play, policies and practices to divide stranger from host city can sometimes "frustrate discrimination," querying the identities separation is meant to preserve. ${ }^{59}$ As the Christians expropriate Barabas's wealth they requisition his house, making him and his daughter Abigail homeless; as she says, they are "placing nuns, / Displacing me" (1.2.253-54). This is a reconfiguring of the distribution and ownership of urban space designed to separate and coerce strangers. Again, this may well have resonated with — or provoked — a London audience. The Elizabethan city exploited the desperation and "willingness" of immigrants "to live in crowded conditions"; this often meant that "property vacant... as a result of the dissolution of the religious houses" was "divided into small tenements and occupied." play attempts to turn back the clock and reverse this reappropriation-someone identified now as a stranger is cast out of their home to allow the city to take back control of a space for religious purposes.

However, to retrieve the riches remaining in their home, Barabas himself reverses the strategy, having Abigail become what Mathias sees as "The strangest sight.../That ever I beheld": a "strangely metamorphos'd nun" (1.2.373-78). As this hybrid, altered figure, her strangeness provokes desire not disgust, and a competition between Christian suitors which Barabas comically and fatally exploits. Making some people different in a city can unsettle the people doing the differentiating, by jeopardising the ideas and methods on which they base the differences they try to create, and by revealing the concatenations between the supposedly different. As Homi Bhabha puts it: “Hybridity represents the ambivalent 'turn' of the discriminated subject into the terrifying, exorbitant object of paranoid classification-a disturbing questioning of the images and presences of authority." 61 Malta is an apposite environment in which to evince this hybridising disruption of authorities reliant on "a coherent identity-alterity binary"; furthermore, this disruption, in a play that triumphed on the London stage, reveals how "the shock of the exotic" in "English culture" stimulated "both attraction and repulsion simultaneously," just as that culture "came gradually to absorb and

\footnotetext{
58 Jonathan Dollimore, Sexual Dissidence: Augustine to Wilde, Freud to Foucault (Oxford: Clarendon Press, 1996), 229.

${ }^{59}$ Bartels, Spectacles, 21.

${ }^{60}$ Pettegree, Foreign Protestant Communities, 283-84.

${ }^{61}$ Homi K. Bhabha, The Location of Culture (1994; repr. London: Routledge, 2000), 113.
} 
adopt various elements of alterity." ${ }^{2}$ This disruptive dynamic was not only informed by London, but also infuses Marlowe's depiction of the instability inherent to other cities which helped constitute London's own identity, namely Rome and Carthage.

\section{Strange Cities: Rome and Carthage}

In Marlowe's rendering of the Roman civil wars recounted in Lucan's First Book, Caesar sets up his conflict with Pompey as a struggle between insiders and outsiders: "Must Pompey's followers, with strangers' aid, / Whom from his youth he brib'd, needs make him king?" (314-15). However, delegitimizing Pompey for his non-Roman backers is disingenuous. Caesar's own troops are a mass of "barbarous bands" (471) from "all quarters" (396) of Rome's Gaulish possessions, listed by the poem over almost seventy (or ten percent) of its seven-hundred-or-so lines. This contact with non-Roman others has had profound effects: Caesar himself is "Like to a lion of scorched desert Afric... / With jaws wide open ghastly roaring out" (208-12), "much chang'd, looking wild and big / And far more barbarous than the French" (475-76). As opposing leaders in Rome's civil war are identified with "strangers' aid" that deforms or exposes their identities, so the identity of Rome itself is "much chang'd" and made very strange as Caesar presses close:

Now evermore, lest some one hope might ease

The commons' jangling minds, apparent signs arose,

Strange sights appear'd, the angry threat'ning gods

Fill'd both the earth and sea with prodigies;

Great store of strange and unknown stars were seen...

And comets that presage the fall of kingdoms;...

Fierce mastiffs howled; the vestal fires went out; ...

Cattle were seen that muttered human speech;

Prodigious births with more and ugly joints

Than nature gives,...

Souls quiet and appeas'd sigh'd from their graves; ...

Shrill voices shright, and ghosts encounter men.... such and more strange

Black night brought forth in secret: (Lucan's First Book, 520-79)

As befits a translation describing breaks in the cosmic crystalline spheres, and the failure of fundamental discriminations between strange and everyday, human and animal, sacred and profane, living and dead, natural and unnatural, this passage also makes periods mingle. This is happening both then and "Now evermore," as ghosts (within and of Lucan) and men meet

\footnotetext{
${ }^{62}$ Daniel Vitkus, Turning Turk: English Theater and the Multicultural Mediterranean, 1570-1630 (New York: Palgrave Macmillan, 2003), 12.
} 
in a present tense "encounter." Shakespeare certainly picked up on the ongoing and haunting resonance of these images of categories blurring in Caesar's imminent triumph in his depiction of the civil strife that accompanied Caesar's end. In Julius Caesar, Cassius says that "the true cause" of the current time of "gliding ghosts," when "all...things change from their ordinance, / Their natures and preformed faculties / To monstrous quality," is Caesar himself:

$$
\text { a man }
$$

Most like this dreadful night

That thunders, lightens, opens graves and roars

As doth the lion in the Capitol:...

$$
\text { prodigious grown }
$$

And fearful, as these strange eruptions are. (Julius Caesar, 1.3.62-78; see also 2.2. $)^{63}$

At the simplest and most profound levels, then, Marlowe's Lucan raises questions about how we work out who is comfortably civilised and who is savagely strange:

Romans, what madness, what huge lust of war,

Hath made barbarians drunk with Latin blood? (Lucan, 8-9)

Civil strife has not only coupled Mars and Venus, "lust" and "war," and allowed others to savage the imperial city; the flexibility and strange shiftiness inherent to Marlowe's translated syntax also suggest how this "lust of war" has "made barbarians" out of Romans who have lost control of themselves. In Dido, Queen of Carthage, Marlowe would conjure more ghosts from Rome's past, to reflect on the present of the capital of the burgeoning proto-empire he inhabited.

In this play, there is a striking scene where the Trojan Aeneas, the destined forefather of Rome (and so, eventually of London, as a new Troy or a new Rome), first sees the walls of the city of Carthage. This scene showcases what happens when the city and the strange come together:

AENEAS. Where am I now? These should be Carthage walls.

ACHATES. Why stands my sweet Aeneas thus amaz'd?...

AENEAS Methinks that town there should be Troy,...

And when I know it is not, then I die. ...

Achates, see, King Priam wags his hand.

$\mathrm{He}$ is alive; Troy is not overcome.

ACHATES. Thy mind, Aeneas, that would have it so,

Deludes thy eyesight; Priamus is dead.

AENEAS. Ah, Troy is sack'd, and Priamus is dead.

And why should poor Aeneas be alive? ...

Enter Cloanthus, Sergestus, Ilioneus [and others]

\footnotetext{
${ }^{63}$ William Shakespeare, Julius Caesar, ed. David Daniell (London: Bloomsbury, 2013).
} 
AENEAS. Lords of this town, or whatsoever style

Belongs unto your name, vouchsafe of ruth

To tell us who inhabits this fair town,

What kind of people, and who governs them;

For we are strangers driven on this shore,

And scarcely know within what clime we are.

ILIONEUS. I heard Aeneas' voice, but see him not,

For none of these can be our general.

ACHATES. Like Ilioneus speaks this noble man,

But Ilioneus goes not in such robes.

SERGESTUS. You are Achates, or I am deceiv'd.

ACHATES. Aeneas, see, Sergestus, or his ghost!...

Enter Dido [with Anna and Iarbas] and her train.

DIDO. What stranger art thou that dost eye me thus?

AENEAS. Sometime I was a Trojan, mighty queen,

But Troy is not, what shall I say I am? ...

DIDO. Brave prince, welcome to Carthage and to me,...

Aeneas is Aeneas, were he clad

In weeds as bad as ever Irus ware. (Dido, Queen of Carthage, 2.1.1-85)

This scene is all the more striking because it is very different from the original Virgil, and to the version Marlowe may have consulted, via Thomas Nashe, in addition to his own translation. ${ }^{64}$ In Thomas Phaer's 1558 rendering of the moment when Aeneas sees Carthage, the hero, we are told, "stood as one amazed / To see the work," but this is because "Eneas wondered at the work where sometimes sheep was fed." Seeing Carthage does prompt reflection in Phaer's Aeneas: "'O happy men whose fortune is your walls now thus to rise'." But here, clearly, any comparison with the fallen Troy is implicit and meant as a contrast. When Aeneas sees the detailed depiction of Troy's fall that Dido has commissioned within Carthage, he is sad- " "Here is a sight for man to mourn"”-yet there is uncanny recognition: "And eke himself he saw among the lords of Greece to be." ${ }^{65}$ But the play takes this much, much further, intensifying both the uncanniness and Aeneas' confusion.

Signalling this moment as uncanny in both Phaer and Marlowe, while more intense in the latter, is appropriate, not only because Marlowe takes an aesthetic experience shared by others and makes it a psychological, private pain. In a way that haunts but differs from Hamlet's encounter with the ghost on the battlements of Elsinore (where others see the

\footnotetext{
${ }^{64}$ See Vivian Thomas and William Tydeman, eds, Christopher Marlowe: The Plays and their Sources (Abingdon: Routledge, 1999), 18: "Marlowe was... an accomplished translator of Latin and had no need to consult any previously published translation of Virgil. He certainly seems to owe nothing directly to Gavin Douglas's translation (1553)...or to Surrey's blank verse translation...(1554, 1557)... There is some evidence...that he knew Thomas Phaer's translation in fourteeners ... It is interesting to note that Thomas Nashe's signature appears on the verso of the title page of the British Library copy of Phaer's translation...[and] traces of Nashe's highly distinctive vocabulary can be detected in the text [of the play]."

65 Thomas Phaer, The seuen first bookes of the Eneidos of Virgill (1558), STC / 368:06, B2v-B3r.
} 
ghost), here no-one other than Aeneas perceives the dead king, and no-one else mistakenly thinks Carthage is Troy. ${ }^{66}$ As Freud suggested, the uncanny has many features, one of which is "the phenomenon of the 'double'." ${ }^{67}$ An unsettling doubling is precisely what Aeneas encounters when he sees himself in Phaer's rendering of Carthage's rendering of Troy, and what Marlowe's Aeneas perceives when he looks on the walls of Carthage-as-Troy. If "himself he saw" in Carthage's images of Troy (in Phaer), or in its similarity to Troy (in the play), this is not "doubling as a preservation against extinction," but doubling as an "uncanny harbinger of death." ${ }^{\prime 68}$ For Marlowe's Aeneas comes to see, of course, that this city is not Troy: the African city is " "unheimlich'...the opposite of 'heimlich' ['homely']...the opposite of what is familiar', and Aeneas is not "heimisch' ['native']." ${ }^{99}$ In exile, he is displaced, dislocated and disorientated, literally unable to tell whether he has gone east or west.

Aeneas' desperate, uncanny repetition of the modal verb "should" tells us a lot about the tension between his desires and his duties, a key concern for this play, but also about the links between strangeness and cities. ${ }^{70} \mathrm{He}$ knows these city walls "should" be Carthage, because that's where he thinks he's meant to be (and, ultimately, meant to leave). Yet, as a vanquished warrior smarting from his losses, he also implies both that Troy "should" not have been destroyed, and that the grandeur of these city walls "should" mean this is actually Troy. The verb's strange plasticity and polyvalence alerts us to Aeneas' estrangement. Even in - or perhaps because of - his alienation and dislocation from both Troy and Carthage, Aeneas experiences the uncanny sensation of déjà $v u$ when faced with this city, "a sense of repetition or 'coming back'."71 Though, as Royle affirms, "there is not a single reference to déjà $v u$ " in 'The Uncanny', Freud does discuss it elsewhere in comparable terms, which suggests "the rapport between the 'uncanny' and déjà $v u . " 72$ Freud describes it as "the peculiar feeling we have, in certain moments and situations, of having had exactly the same experience once before or of having once been in the same place."73 But in Aeneas' case, this

\footnotetext{
${ }^{66}$ Hamlet will, of course, later ask to hear lines from the players about "Aeneas' tale to Dido...especially where he speaks of Priam's slaughter" (2.2.390-91); The Complete Works, eds. Jonathan Bate and Eric Rasmussen (Houndmills: Macmillan, 2008).

${ }^{67}$ Freud, "The Uncanny," 356.

${ }^{68}$ Freud, 356-57.

${ }^{69}$ Freud, 341.

${ }^{70}$ For one rendering of the desire/duty conflict, see Sara Munson Deats, "Dido, Queen of Carthage and The Massacre at Paris," in The Cambridge Companion to Christopher Marlowe, ed. Patrick Cheney (Cambridge: Cambridge University Press, 2009), 193-206.

${ }^{71}$ Royle, The Uncanny, 2.

${ }^{72}$ Royle, 178, 173.

${ }^{73}$ Freud, "Determinism, Belief in Chance and Superstition-Some Points of View," in The Penguin Freud

Library V: The Psychopathology of Everyday Life, ed. Angela Richards (Harmondsworth: Penguin, 1991), 328.
} 
sensation of déjà $v u$ betrays a difference between his wishful thinking and reality, hence Achates echoing yet modifying the verb from "should" to "would." Why wish it was Troy? Because then Troy would not be destroyed and Aeneas would not suffer survivors' guilt as dutifully as he does; if it is Carthage, "why should poor Aeneas be alive?" If it was Troy, Aeneas would be alive, fully and legitimately (and Priam would be too). When Aeneas knows it is not, he says, "I die." If he is caught between Troy and Carthage, life and death (his own and Priam's) he is enduring a form of the uncanny concerned not only with the strange return promised by déjà $v u$, but also with "the return of the dead...spirits and ghosts." 74

What Aeneas is actually coming to terms with is his status as exile, as one of many "strangers...on this shore" at the walls of "this fair town:" "Where am I now?...What shall I say I am?" To do so, and answer his questions, though, he must surrender to the uncanny sense of "the experience of oneself as a foreign body." 75 The "self-estrangement of selfreflection" that Davies identifies as uniquely present in Shakespearean language is precursively apparent here, too. ${ }^{76}$ Yet even as we see Aeneas accepting this status as stranger to the city of Carthage, as in those lines, the play wrong-foots us again, to complicate our understanding of who or what is strange. Those men of Aeneas', like Ilioneus, who scouted Carthage before him are, like him, "strangers" to the place, but they now do not look like it because they are dressed like locals. Aeneas, in turn, assumes he is a stranger to them, when he is not really. Achates, with Aeneas, thinks one of these other men is Sergestus' double, "or his ghost!"; for their part, the scouts hear Aeneas "but see him not.” Again, like Troy itself, in Aeneas' memory or Carthaginian rendering, figures are and are not present. Defining who is a stranger gets even more confusing because although Aeneas is, to Dido, at first a "stranger," she very quickly appears to go on to give him back and validate his identity: "Aeneas is Aeneas." He is, apparently a stranger no more, and has found a new home.

This would be credible, if not for the fact that from beginning to end, we are convinced of Aeneas' status as a stranger. The first person Aeneas meets in north Africa, who happens to be his mother in disguise, calls him a "stranger" (1.1.203). The bitterly jealous Iarbas wonders why Dido canoodles with a "stranger" (3.3.11), and why she mourns "a stranger's flight" (5.1.279). Dido herself comes to realise she has been "entangled by a stranger's looks" (5.1.145), and promises to "consume" in fire "all that this stranger left"

\footnotetext{
${ }^{74}$ Freud, "The Uncanny," 364; on the same page, Freud notes: "some languages in use to-day can only render the German expression 'an unheimlich house' by 'a haunted house'."

${ }^{75}$ Royle, The Uncanny, 2.

${ }^{76}$ Davies, Shakespeare Thinking, 15.
} 
(5.1.285). It would seem that Aeneas is Aeneas not because he stays but because he leaves Dido, thereby fulfilling his divinely-ordained destiny to found Rome, and the narrative logic of the myth.

So is he, or is Carthage, strange or not? Freud reminds us that what is familiar and unfamiliar, strange and normal, are not always so distinct in language, culture and psychology, however much people make try to make them so: "Unheimlich is in some way or other a subspecies of Heimlich. ... the unheimisch is what was once heimisch, familiar; the prefix ' $u n$ '... is the token of repression." "77 This can be put differently, and in relation to what Marlowe's work expresses rather than represses, as Bartels realised: "what is out there and what is in here are not so different after all." 78 The familiar is stranger, and the stranger more familiar, than we thought.

\section{Conclusion: London, Strange City}

Though we cannot know exactly when and where Dido was first performed, Aeneas' uncanny confusion about who he is when faced with this city, may well have been an audience's. ${ }^{79}$ If, as Deanne Williams and others have suggested, Dido—as “"Eliza"” (4.2.10)—is a refracted figuring of Elizabeth I, perhaps Aeneas' uncanny dislocation at Carthage's walls evoked strangers' experiences on perceiving Elizabeth's London. ${ }^{80}$ And so if you were a stranger to an English city, whether from the Continent or another part of the British Isles (and there were lots of these at the time), you would know how Aeneas felt. ${ }^{81}$ But even if you felt at home in an English city, you would be seeing how easy (and how hard to take) it could be to end up feeling like "strangers hereafter," to recollect Henry Finch's words, and how easy it could be to mistake a city London modelled itself on, like Troy, for another one. Works such as John Stow's 1598 Survey of London revealed that early modern city to be haunted by the past, as a palimpsestic space of multiple histories. To others writing around the same time, a living city could also be a necropolis, with plague pits, cemeteries, monuments, morbidity and mortality. London, in particular, was "a dead world indeed," whose morally and

\footnotetext{
${ }^{77}$ Freud, “The Uncanny," 347, 368.

${ }^{78}$ Bartels, Spectacles, 24.

${ }^{79}$ Martin Wiggins, "When Did Marlowe Write Dido, Queen of Carthage?," Review of English Studies 59, no. 241 (September 2008): 521-41.

${ }^{80}$ Deanne Williams, “Dido, Queen of England,” English Literary History 73, no. 1 (2006): 31-59.

${ }^{81}$ Pettegree notes: "The real problem [in the 1590s]... was that in the last decade of the reign, London was inundated by a rising tide of newcomers from other parts of England...[r]eturning soldiers, unemployed labourers, 'masterless men' and vagabonds." Foreign Protestant Communities, 293.
} 
physically diseased inhabitants had "dead souls." ${ }^{82}$ In the city, as Aeneas also realises at Carthage's walls, the boundaries between the living and the dead, being and not being, were not certain: "Cities are sepulchres; they who dwell there / Are carcases, as if no such there were." $" 83$

The likes of Edmund Spenser might have sought to emulate and revive Virgil in order to emphasise England's and London's "anciently deriu'd" Roman and thus Trojan civilising, imperialist roots. ${ }^{84}$ But by hybridizing "English and Carthaginian, European and African" in the figure of Dido (and perhaps Elizabeth), and also by making Aeneas stay strange, and feel uncannily estranged, Marlowe represents strange cities that make strangeness integral to English identity, within and beyond London. ${ }^{85}$ Marlowe's critique of the translatio imperii ideal, replaced with a "poetics" of "counter-nationhood" in order to "trouble and darken the idea of patriotism," proved prescient. ${ }^{86}$ London might have been a new Troy, or a new Rome, but Marlowe was not the last to realise what made it so:

I London, that haue beene styled by Strangers, Emporium celeberrium totius Orbis; The most famous Citie and Marketplace of the whole World. By others styled, Trinobantum, I. Troynovant or New Troy: by others Augusta, I. ${ }^{87}$

Like Marlowe, this passage implies that strangers have "styled," that is named or termed, what we understand early modern London to be. But, like Marlowe, these lines also imagine how strangers make the city what it is, with the labour of their bodies and minds, and with their different languages. And like this passage, Marlowe's writing for the London stage and beyond shows how vital it is not to be "forgetful" that these terms, perceptions and constructions can be internalised by a city itself, a city speaking in the defamiliarising

\footnotetext{
${ }^{82}$ Francis White, "London's Warning, by Jerusalem" (1619), in London in the Age of Shakespeare, ed. Lawrence Manley (London: Croom Helm, 1986), 111.

${ }^{83}$ John Donne, “To Sir Henry Wotton" ("Sir, more than kisses”), in John Donne's Poetry, ed. Donald R. Dickson (New York: Norton, 2007), 55.

${ }^{84}$ Edmund Spenser, The Faerie Queene, ed. A. C. Hamilton (London: Routledge, 2006), 2.10.5-13. On London as Troy, see Lawrence Manley, Literature and Culture in Early Modern London (Cambridge: Cambridge University Press, 1995), 182-85; and Peter Lake, "From Troynouvant to Heliogabalus's Rome and back: 'order' and its others in the London of John Stow," in Imagining Early Modern London: Perceptions and Portrayals of the City from Stow to Strype 1598-1720, ed. J. F. Merritt (Cambridge: Cambridge University Press, 2001), 21749 .

${ }^{85}$ Williams, "Dido," 42.

${ }^{86}$ Patrick Cheney, Marlowe's Counterfeit Profession: Ovid, Spenser, Counter-Nationhood (Toronto: Toronto University Press, 1997), 21, 25. On Marlowe's treatment of the translatio imperii model in this play see Bartels, Spectacles, 29-52; and Lisa Hopkins, Christopher Marlowe, Renaissance Dramatist (Edinburgh: Edinburgh University Press, 2008).

${ }^{87}$ Anon. Lachrymae Londinenses, or Londons Lamentations (London, 1626), STC / 580:03, 1.
} 
tongues of "Itrãgers" who "lodge" there, who, if not "Angels" themselves, are making homes away from home. ${ }^{88}$ Marlowe's works remind audiences past and present that a city like London can be strange to many, not just strangers.

\section{Bibliography}

Adorno, Theodor. Minima Moralia: Reflections from Damaged Life, translated by E. F. N. Jephcott. 1974. Reprint, London: Verso, 2000.

Anon. Lachrymae Londinenses, or Londons Lamentations. London, 1626. STC / 580:03. Archer, Ian. "The Nostalgia of John Stow." in The Theatrical City: Culture, Theatre and Politics in London 1576-1649, edited by David L. Smith, Richard Strier and David Bevington, 17-34. Cambridge: Cambridge University Press, 1995.

Bartels, Emily C. Spectacles of Strangeness: Imperialism, Alienation and Marlowe. Philadelphia: University of Pennsylvania Press, 1993.

Bartels, Emily and Emma Smith, eds. Christopher Marlowe in Context. Cambridge: Cambridge University Press, 2015.

Bauman, Zygmunt. Strangers at Our Door. Cambridge: Polity, 2016.

Bhabha, Homi K. The Location of Culture. 1994. Reprint. London: Routledge, 2000.

Brigden, Susan. New Worlds, Lost Worlds: The Rule of the Tudors, 1485-1603. Harmondsworth: Penguin, 2000.

Bucholz, Robert O. and Joseph P. Ward, eds. London: A Social and Cultural History, 15501750. Cambridge: Cambridge University Press, 2012.

Chambers, E. K. The Elizabethan Stage. 4 vols. Oxford: Clarendon Press, 1923.

Cheney, Patrick. Marlowe's Counterfeit Profession: Ovid, Spenser, Counter-Nationhood. Toronto: Toronto University Press, 1997.

Davies, Philip. Shakespeare Thinking. London: Continuum, 2007.

Deats, Sara Munson. “Dido, Queen of Carthage and The Massacre at Paris." In The Cambridge Companion to Christopher Marlowe, edited by Patrick Cheney, 193-206. Cambridge: Cambridge University Press, 2009.

D'Ewes, Sir Simonds. The Journals of All the Parliaments During the Reign of Queen Elizabeth. Shannon, Ireland, 1682.

\footnotetext{
${ }^{88}$ See Hebrews, 13:2 (Geneva Bible, 1560): "Be not forgetful to lodge Jtrãgers: for thereby fome haue receiued Angels into their houles unawares."
} 
Dionne, Craig. "Fashioning Outlaws: The Early Modern Rogue and Urban Culture.” In Rogues and Early Modern English Culture, edited by Craig Dionne and Steve Mentz, 33-62. Ann Arbor: University of Michigan Press, 2004.

Dollimore, Jonathan. Sexual Dissidence: Augustine to Wilde, Freud to Foucault. Oxford: Clarendon Press, 1996.

Donne, John. John Donne's Poetry. Edited by Donald R. Dickson. New York: Norton, 2007.

Duxfield, Andrew. Christopher Marlowe and the Failure to Unify. Farnham: Ashgate, 2015. Fehrenbach, Robert J., Lea Ann Boone, and Mario A. Di Cesare, eds. A Concordance to the Plays, Poems, and Translations of Christopher Marlowe. Ithaca, NY: Cornell University Press, 1984.

Fiedler, Leslie A. The Stranger in Shakespeare. St. Albans: Paladin, 1974.

Freeman, Arthur. "Marlowe, Kyd, and the Dutch Church Libel." 3, no. 1 (Winter 1973): 4452

Freud, Sigmund. "Determinism, Belief in Chance and Superstition-Some Points of View." In The Penguin Freud Library V: The Psychopathology of Everyday Life, edited by Angela Richards, 300-44. Harmondsworth: Penguin, 1991.

—. "The Uncanny." In The Penguin Freud Library XIV: Art and Literature, edited by Albert Dickson, 339-76. Harmondsworth: Penguin, 1990.

Greenblatt, Stephen. Renaissance Self-Fashioning: From More to Shakespeare. Chicago: University of Chicago Press, 1980.

Griffin, Eric. "Shakespeare, Marlowe and the Stranger Crisis of the Early 1590s." In Shakespeare and Immigration, edited by Ruben Espinosa and David Ruiter, 13-36. Farnham: Ashgate, 2016.

Hoffman, Eva. Lost in Translation: A Life in a New Language. London: Vintage, 1998. Honan, Park. Christopher Marlowe: Poet and Spy. Oxford: Oxford University Press, 2005. Hopkins, Lisa. Christopher Marlowe, Renaissance Dramatist. Edinburgh: Edinburgh University Press, 2008.

Howard, Jean E. Theater of a City: The Places of London Comedy, 1598-1642. Philadelphia: University of Pennsylvania Press, 2007.

Kermode, Lloyd Edward. Aliens and Englishness in Elizabethan Drama. Cambridge: Cambridge University Press, 2009.

Lake, Peter. 'From Troynouvant to Heliogabalus's Rome and back: 'order' and its others in the London of John Stow.” In Imagining Early Modern London: Perceptions and 
Portrayals of the City from Stow to Strype 1598-1720, edited by J. F. Merritt, 217-49. Cambridge: Cambridge University Press, 2001.

Levin, Harry. The Overreacher: A Study of Christopher Marlowe. London: Faber and Faber, 1954.

Manley, Lawrence. Literature and Culture in Early Modern London. Cambridge: Cambridge University Press, 1995.

Marlowe, Christopher. Christopher Marlowe, Complete Plays and Poems, edited by E. D. Pendry. London: Everyman, 1995.

McEachern, Claire. The Poetics of English Nationhood, 1590-1612. Cambridge: Cambridge University Press, 1996.

Mullaney, Steven. The Place of the Stage: License, Play, and Power in Renaissance England. Chicago: University of Chicago Press, 1995.

Oakley, Anne M. “The Canterbury Walloon Congregation from Elizabeth I to Laud.” In Huguenots in Britain and Their French Background, 1550-1800, edited by Irene Scouloudi, 56-71. Totowa, NJ: Barnes and Noble, 1987.

Oldenburg, Scott. Alien Albion: Literature and Immigration in Early Modern England. Toronto: University of Toronto Press, 2015.

Pettegree, Andrew. Foreign Protestant Communities in Sixteenth-Century London. Oxford: Clarendon Press, 1986.

Phaer, Thomas. The seuen first bookes of the Eneidos of Virgill. 1558. STC / 368:06.

Platter, Thomas and Horatio Busino. The Journals of Two Travellers in Elizabethan and Early Stuart England: Thomas Platter and Horatio Busino, edited by Peter Razell. London: Caliban Books, 1995.

Prockter, Adrian and Robert Taylor. The A to Z of Elizabethan London. Kent: Harry Margary, 1979.

Riggs, David. The World of Christopher Marlowe. London: Faber and Faber, 2004.

Royle, Nicholas. The Uncanny. Manchester: Manchester University Press, 2003.

Sennett, Richard. Flesh and Stone: The Body and the City in Western Civilization. London: Faber and Faber, 1996.

Shakespeare, William. The Complete Works, edited by Jonathan Bate and Eric Rasmussen. Houndmills: Macmillan, 2008.

—_ Julius Caesar, edited by David Daniell. London: Bloomsbury, 2013.

Spenser, Edmund. The Faerie Queene. Edited by A. C. Hamilton. London: Routledge, 2006. 
Thomas, Vivian and William Tydeman, eds. Christopher Marlowe: The Plays and their Sources. Abingdon: Routledge, 1999.

Travis, Alan. "Immigration bill: Theresa May defends plans to create 'hostile environment'." The Guardian, 10 October 2013.

https://www.theguardian.com/politics/2013/oct/10/immigration-bill-theresa-mayhostile-environment

Vitkus, Daniel. Turning Turk: English Theater and the Multicultural Mediterranean, 15701630. New York: Palgrave Macmillan, 2003.

White, Francis. "London's Warning, by Jerusalem" (1619). In London in the Age of Shakespeare, edited by Lawrence Manley, 110-11. London: Croom Helm, 1986.

Wiggins, Martin. "When Did Marlowe Write Dido, Queen of Carthage?" Review of English Studies 59, no. 241 (September 2008): 521-41.

Williams, Deanne. “Dido, Queen of England.” English Literary History 73, no. 1 (2006): 3159.

Wright, Laura. "Speaking and listening in early modern London." In The City and the Senses: Urban Culture Since 1500, edited by Alex Cowan and Jill Steward, 60-74. Aldershot: Ashgate, 2007.

Yungblut, Laura Hunt. Strangers Settled Here Amongst Us: Policies, perceptions and the presence of aliens in Elizabethan England. London: Routledge, 1996. 